\title{
Információs páncélszekrény az emberi jogok védelmére
}

$\mathbf{N}$

A társadalmi vállalkozások a társadalmi érték növelésével járulnak hozzá a társadalmi és gazdasági különbségek csökkentéséhez. A Szilícium-völgy egyik nem nyereség-érdekeltségű informatikai vállalkozása, a Benetech cég által kifejlesztett Martus számítógépes rendszer az emberi jogok súlyos sérelmeit feltáró és azokról tudósító civil szervezetek, aktivisták, újságírók számára készült. A rendszer célja egy biztonságos „információs páncélszekrény” biztosítása, tekintettel arra, hogy az emberi jogok sérelmeit feltáró beszámolók szerzői gyakran veszélyes körülmények között, információik megsemmisítésétől fenyegetve dolgoznak, s tudósításaik eredetiségét, hitelességét nehéz bizonyítani.

\section{Szerzői információ:}

\section{László Gábor}

Egyetemi tanulmányait a Veszprémi Egyetem múszaki menedzser szakán végezte, majd a BGF Külkereskedelmi Főiskolai karán szerzett külkereskedelmi irányítás szakértối oklevelet. Jelenleg a BME Múszaki Menedzsment Doktori iskola hallgatója. Kutatási témája az információstratégiák és a nyílt forráskód területe. Kutatási területéhez kapcsolódóan számos hazai és nemzetközi konferencián vett részt. Munkahelyén, a Budapesti Múszaki Fóiskola Keleti Károly Gazdasági Fóiskolai Karán múködő ITOK vezetốje.

Így hivatkozzon erre a cikkre:

László Gábor. „Információs páncélszekrény az emberi jogok védelmére”. Információs Társadalom V, 1. szám (2005): 94-102.

$=$ https://dx.doi.org/10.22503/inftars.V.2005.1.7 $\rightleftharpoons$

A folyóiratban közölt müvek

a Creative Commons Nevezd meg! - Ne add el! - Így add tovább! 4.0

Nemzetközi Licenc feltételeinek megfelelöen használhatók. 
Lás zló Gábor

\title{
Információs páncélszekrény az emberi jogok védelmére
}

\begin{abstract}
„Minden ember önmagában véve értékes. Olyan elidegeníthetetlen jogokkal rendelkerik, melyeket senki sem sérthet meg. Minden embernek joga van arra, hogy saját céljait kövesse és senki ne használja ốt puszta eszközként saját céljaira."

Milton Friedman, Nobel díjas amerikai közgazdász
\end{abstract}

\section{Bevezetés}

Az amerikai Bill Drayton meggyốzốdése szerint a társadalmi problémák kezelésére a leghathatósabb módszer a társadalmi vállalkozás (social entrepreneurship). Amikor 1980-ban ezzel a gondolattal megalapította az Ashoka elnevezésú szervezetet, a társadalmi vállalkozások fogalma még ismeretlen volt: „Drayton úr, aki az Ashoka megalapítója és elnöke, a kockázati tóke-befektetés modelljét adaptálva a civil szektorra, a tốke mozgósítására törekedett. Az alapötlet az volt, hogy megkeressék a kezdő újítókat, támogassák óket anyagilag és összekapcsolják óket egy globális tagsági hálózatba."

Az azóta eltelt évek ốt igazolták: a társadalmi vállalkozás elfogadott fogalommá és üzleti modellé vált, és a társadalmi vállalkozások száma egyre növekvóben van. A kifejezést sokféleképpen értelmezik. Van, aki csupán valamilyen nonprofit szervezet felállítását és múködtetését érti alatta, míg mások értelmezése szerint ez az üzleti forma a nonprofit szervezet profitorientált vállalkozását jelenti. Megint más megközelítés szerint azok a vállalkozások nevezhetók társadalmi vállalkozásnak, amelyeknek a mindennapi múködését áthatja a társadalmi felelôsség.

A társadalmi vállalkozások fogalmára nehéz jó definíciót adni. A társadalmi problémák kezelésére és a társadalmi érték növelésére a hagyományos üzleti vállalkozások mivel a céljuk nem ez, hanem a profit - nem alkalmasak. A társadalmi vállalkozások ugyanazon a piacon múködnek, ugyanolyan feltételek mellett, mint a hagyományos vállalkozások, ám azzal a különbséggel, hogy az elért nyereséget a társadalmi haszon növelése érdekében használják fel. Versenybe szállnak különbözó adományokért és önkéntes segítségért is. A legfóbb különbség azonban a motivációban rejlik.

\section{A Benetech-kezdeményezés}

A Benetech-kezdeményezés olyan filantropikus modellt nyújt, ami egyesíti az innovatív társadalmi vállalkozást a hagyományos, szigorú üzleti modellel. Erôs technológiai irányultsága különbözteti meg a legtöbb nonprofit szervezettól.

A vakok és látásukban korlátozott személyek számára készült, s a cég számára nagy sikert és egyúttal komoly bevételeket hozott Bookshare ${ }^{2}$ fájl-cseréló program elké-

${ }^{1}$ The New York Times. http://www.ashoka.org/hu/main/kerdesek.cfm

${ }^{2}$ A http://www.benetech.org/projects/bookshare.shtml http://www.bookshare.org/web/Welcome.html címen bóséges információ található a rendszer múködéséról. 
szítése és üzembe állítása után a Benetech cég - második nagyobb projektjeként - megkezdte az elókészületeket az emberi jogi csoportok számára készített szoftver teszteléshez. Ez a szoftver az emberi jogi aktivisták számára biztosítja, hogy bizalmasan kezelve, biztonságosan tárolhassák az emberi jogok megsértését jelentố eseményekról készült feljegyzéseiket, és bármikor, bárhonnan nyilvánosságra hozhassák azokat. Ez az alkalmazás a Martus nevet viseli. A program kidolgozásakor a Benetech felhasználta az Amnesty International, az „Emberi jogi figyelószolgálat” (Human Rights Watch), az emberi jogokat védő ügyvédek szervezete (Lawyers' Committee for Human Rights), valamint az ENSZ megjegyzéseit és észrevételeit. Soros György „Nyílt Társadalom Intézete” (Open Society Institute) 250 ezer dollárral támogatta a fejlesztést.

A nagy IKT-cégek nem versenytársként tekintettek a Benetech kezdeményezésre, hanem meglátták és kihasználták a hozzájuk hasonló technológiai irányultságú társadalmi vállalkozás támogatásában rejlő lehetőségeket, s ezáltal ók is pozitívan értékelt közéleti szerephez jutottak. Az IBM, a SUN, a Hewlett-Packard és a Fujitsu különféle berendezéseket is adományoztak a Benetech számára.

Hogyan segítheti a technológia az emberi jogok érvényesülését?

Az emberi jogok területén fontos szerepet játszik az információ és a nyilvánosság. Az itt tevékenykedő civil szervezetek legértékesebb vagyontárgya az információ, ami szinte az egyetlen eszközük az emberi jogok megsértése elleni küzdelemben. Ezek a civil szervezetek információkat gyújtenek az emberi jogok megsértéséról, hogy ráirányítsák a figyelmet az áldozatok helyzetére. A nemzetközi civil szervezeteknek az a céljuk, hogy az eseményekról összegyújtött információkat - a közvéleményben való tudatosítás, a politikai nyomás-gyakorlás és az igazságszolgáltatás érdekében - a média érdeklődésének középpontjába állítsák. Az emberi jogok érvényesítése érdekében folytatott kampányok a sérelmekre vonatkozó információk összegyújtése és felhasználása nélkül csak mérsékelt sikerre számíthatnak.

A sikeres érdekérvényesítés, a megfelelő információk összegyưjtése és felhasználása érdekében a civil szervezeteknek képesnek kell lenniük az igényeiknek megfelelő jelentések elektronikus formátumban előállítására, az adatállomány biztonságos tárolására és védelmére, valamint arra, hogy bármikor hatékonyan és biztonságosan hozzáférhessenek az így tárolt információkhoz.

Az amerikai tudomány-fejlesztési társaság (American Association for the Advancement of Science) becslése szerint világszerte körülbelül tízezer olyan emberi jogi civil szervezet létezik, amelyek adatokat gyújtenek ezen a területen. Ezek a szervezetek különféle módokon készítik el és tárolják feljegyzéseiket, melyeknek formai skálája a kézzel, illetve írógéppel írt jegyzetektốl a számítógépes programokkal előállított dokumentumokig terjed. A sokszínúség azt eredményezi, hogy ezek a feljegyzések átláthatatlan és rendszertelen szerkezetben jelennek meg, ami nehézkessé vagy szinte lehetetlenné teszi az információk megosztását az egész emberi jogi szektorban. Ugyanakkor ezek a feljegyzések a biztonságos helyi tárolás nehézségei miatt hihetetlen módon sérülékenyek: ki vannak téve a megrongálódás vagy megsemmisülés, a szándékos rongálás vagy megsemmisítés, és az elkobzás vagy az ellopás veszélyének egyaránt.

$\mathrm{Az}$ adatvesztésnek a felhasználói hibáktól kezdve a környezeti hatásokon át az adathordozó eltulajdonításáig vagy megsemmisítéséig nagyon sok oka lehetséges. A va- 
lós élet mindig produkál újabb és újabb meglepetéseket. Egy Srí Lankán múködố nonprofit intézmény esetében például termeszek ették meg az emberi jogok megsértésére vonatkozóan hét évre visszanyúlóan dokumentált iratanyagot, ami papír-formában volt tárolva. Gyakori eset a számítógépek eltulajdonítása. Az „információs páncélszekrény" ezeket a (környezeti) hatásokat nem védheti ki, az adatvesztést azonban megakadályozza, s így azok az információk nem vesznek el, amelyeknek a megosztása és nyilvánosságra hozatala mind helyi, mind regionális vagy akár globális viszonylatban alapvetó fontosságú az érintett szervezetek számára.

Sok esetben megtörtént, hogy az összegyújtött információk megsemmisültek, a feljegyzéseket elkobozták és elsikkasztották. Ezek az események megnehezítik, vagy éppen lehetetlenné teszik az információk valós bizonyítékként való felhasználását az ügyészség, a bíróság vagy a civil szervezetek számára, és megakadályozzák az elkövetók elszámoltatását.

Az emberi jogokkal foglalkozó szervezetek részéról egyre erôsebb, sürgetố igény fogalmazódott meg egy olyan eszköz iránt, melynek segítségével a fenti problémák kiküszöbölhetőek. Olyan eszközre volt szükség, amellyel az emberi jogok megsértéséról elkészített jelentések összegyưjithetốk, rendszerezhetớk és biztonságosan tárolhatók, s ezzel lehetốség nyílik a figyelem felhívásával elôsegíteni a búnösök felelôsségre vonását és akadályokat gördíteni hasonló cselekmények megismétlódése elé. Ezeknek az igényeknek a kielégítésére dolgozta ki a Benetech cég a Martus rendszert.

\section{A Martus rendszer}

A Martus görög eredetû szó, jelentése: tanú. A Martus segítségével az emberi jogok sérelmeit feltáró és azokról tudósító aktivisták, civil szervezetek és újságírók olyan információtechnológiai eszközhöz - az interneten keresztül elérhetố,információs páncélszekrényhez" - jutottak, amely a legfontosabb feladatuk ellátásában, az emberi jogok megsértéséról rendelkezésükre álló információik rendszerezésében, tárolásában és nyilvánosságra hozatalában segítheti óket. E beszámolók írói, az eseményekról fényképeket vagy videó-felvételeket készítő személyek ugyanis gyakran különösen nehéz és veszélyes körülmények között, információik megsemmisítésétól fenyegetve dolgoznak, s tudósításaik hitelességét is nehéz bizonyítaniuk. A Martus használatával - a biztonságos tárolásnak köszönhetốen - hatékonyan kivédhetốk az elkészült dokumentumok elleni lehetséges támadások és jelentôsen csökken az adatok megsemmisülésének kockázata.

A Martus nem szervezet vagy szervezetek hálózata, hanem az emberi jogi civil szervezetek számára, azok sajátságos technológiai igényeihez alkalmazkodóan kifejlesztett eszköz. Célja olyan szolgáltatás biztosítása a civil szervezetek számára, amely elôsegíti az emberi jogok védelmét, lerövidítve az emberi jogok sérelmére elkövetett búnökre adandó válaszok reakció-idejét és sok esetben megakadályozva a további visszaéléseket. A Martus független a kormányoktól és a rendszert használó civil szervezetektól is.

A Martus adatvédelmi rendszere védi az információkat a megsemmisüléstól vagy a megsemmisítéstól. Megốrzi az összegyújtött információkat és biztosítja azok nyilvánosságra hozatalát. A kutatók számára elôsegíti a sérelmek mélyebb feltárását több szemtanú információi alapján, míg a szemtanúk számára lehetốvé teszi, hogy bizonyos részleteket titkosan kezeljenek. Az aktivisták, az ügyészek, az újságírók és a nyilvánosság számára egyaránt hozzáférhetővé teszi az emberi jogok megsértésében érintettek beszámolóit. 
A program elkészítése során gondot fordítottak arra, hogy használata minél egyszerúbb legyen. Ahhoz, hogy a Martus rendszerét valaki használni tudja, mindössze alapvetô e-mail kezelési ismeretekkel kell rendelkeznie. A bevezetés kezdeti fázisában a Martus személyzete ingyenes oktatást biztosított az olyan civil szervezetek részére, melyek csatlakoztak a programhoz, de nem tudtak fizetni érte. A Martus esetében is szükség van egy bizonyos „,kritikus tömeg” elérésére ahhoz, hogy a szolgáltatás valóban jól érzékelhetố hatásokat érhessen el. Több oldalról is megfogalmazták azt a célt, hogy a Martus bekerüljön a civil szervezetek által használt alapvető technológiák közé. A növekvố felhasználói szám mellett a szükséges oktatást egyre inkább átvállalja a Martus személyzetétốl maga a felhasználói közösség.

\section{A Martus felhasználói}

A Martus felhasználói közössége a következő három, jól elkülöníthetố csoportra osztható fel: az információk elóállítói, a megbízható közvetítók és az információk felhasználói. Az információk előállítói a Martus szoftver segítségével az emberi jogok megsértésével összefüggő ügyekben elkészítik jelentéseiket. A megbízható közvetítók azok a fontosabb intézmények, amelyek a Martus rendszer szervereit üzemeltetik és biztonságos, megbízható szolgáltatásokat nyújtanak az információk elóállítói és felhasználói számára egyaránt. Az információk fogyasztói közé tartoznak a nagyobb emberi jogi szervezetek, amelyek a Martus rendszerét kutatásra, illetve az emberi jogok megsértéséról szóló tanulmányok és beszámolók elkészítéséhez használják fel, továbbá az akadémiai szféra, és nem utolsósorban a tömegtájékoztatási eszközök.

\section{A Martus fejlesztésének folyamata}

A rendszer kidolgozása elótt és a munka folyamán a Martus fejlesztôi számos nemzetközi emberi jogi szervezet, köztük a Human Rights Watch, a Lawyers' Committee for Human Rights (új nevén: Human rights First), a Nyílt Társadalom Intézete (Open Society Institute), a Nyílt Társadalom Archívum (Open Society Archive), ${ }^{3}$ az ENSZ és az Amnesty International képviselóivel folytattak megbeszéléseket, összesen 12 országban. A szervezetek képviselối által megfogalmazott ajánlásoknak a rendszerbe való beépítése érdekében ezen kívül piackutatást végeztek Oroszországban, Srí Lankán, Kambodzsában

${ }^{3}$ „A Nyílt Társadalom Archívum jelenlegi legfontosabb feladata az emberi jogok kérdéseivel, az emberi jogok fejlődésével, illetve azok megsértésével kapcsolatos anyagok, gyújtemények gyarapítása. Az emberi jogok kérdése történetileg a kommunizmus és a posztkommunista korszak közötti összekötố kapocs. Az emberi jogok ügye egyre nagyobb szerepet kapott a hidegháború utolsó korszakában, a nemzetközi viszonyok alakulásában éppúgy, mint a volt szovjet blokk országainak belsốátalakulásában. A pártállamok belsố ellenzéke érvkészletét jelentős mértékben az emberi jogok politikai és filozófiai hagyományából merítette, és erkölcsi alapon támadta a fennálló rezsimeket. Ám a kommunizmus bukása nemcsak megoldást jelentett, amint azt a jugoszláviai polgárháború is bizonyította. A nemzeti önrendelkezés és a kisebbségi jogok körüli konfliktusok számos posztkommunista régióban az emberi jogok tömeges sérelméhez vezettek. A Nyílt Társadalom Archívumának érdeklôdése ezért is fordult már kezdettól fogva az emberi jogok sérelmének dokumentációja felé.” 
és Guatemalában. A Martus rendszerét kiterjesztett tesztelésnek vetették alá Srí Lankán, Gutemalában, Oroszországban és Kelet-Európában. A szoftvert 2003. január 15-én tették hozzáférhetôvé a nyilvánosság számára. A civil szervezetek részére - a média segítségét is felhasználva - külön bemutatókat szerveztek. A Martus képviselói nemzetközi emberi jogi konferenciákon is népszerúsítik a szolgáltatást, s emellett egyedileg is felkeresnek számos civil szervezetet, részletesen megvilágítva, hogy a Martus rendszere hogyan segítheti munkájukat.

A Martus kifejlesztése és a szükséges oktatás költségei közel 650 ezer dollárt tettek ki. Ezt az összeget - többek között a Nyílt Társadalom Intézete és a nagy IKT-cégek adományai mellett - elsôsorban a Benetech vállalat anyagi eszközei fedezték. A továbblépéshez, a rendszer kiterjesztéséhez és fejlesztéséhez további pénzeszközök szükségesek. Ezeket a forrásokat a nagyobb civil szervezetek számára végzett, testre szabott egyedi fejlesztések és a szerver- üzemeltetók számára nyújtott szolgáltatások biztosítják. A Martus nem kap közvetlen állami támogatást, de a fejlesztốk elfogadják a nekik juttatott adományokat.

\section{A Martus felhasználási területei}

A Martus rendszere például a nókkel szemben elkövetett erôszak és egyéb jogsértések, a kínzás és a népirtás búntetteinek vádlottjai ellen folytatott jogi eljárások alátámasztására, továbbá a közszférában a választási csalások és a korrupció leleplezésére, valamint - az etnikai és vallási üldöztetés és az általános emberi jogok megsértése elleni küzdelem eszközeként - az ilyen eseményekról készült tudósítások dokumentálására szolgálhat. A lehetôségek azonban sokkal szélesebb felhasználási területet ölelhetnek fel, a rendszer segíthet például a családoknak eltúnt családtagjaik felkutatásában, vagy éppen a környezetszennyezések felderítésében. A rendszer szinte mindazoknak a szervezeteknek a dokumentációs igényeit kielégíti, amelyek a társadalmi igazságosság megteremtésében érdekeltek.

\section{Az információs páncélszekrény - a Martus múködése}

A nyers, feldolgozatlan adatok tárolásához és visszakereséséhez - azokhoz az iparágakhoz hasonlóan, ahol az információ mint termék jelenik meg - az emberi jogok védelmével foglalkozó szervezetek esetében is független, biztonságos rendszerre van szükség. Ha az információk rendelkezésre állnak, felhasználóik tanulmányozni és elemezni tudják óket, tanulmányokat és jelentéseket publikálhatnak, vagy akár közvetlen lépéseket is tehetnek, például nyomozás vagy búnvádi eljárás lefolytatását kérhetik a fennálló jogsértések megszüntetésére.

A Martus rendszer - felépítését tekintve - három elkülöníthetô elemból tevődik össze: egy központi szerverból, az interneten hozzá kapcsolódó, a Martus kliens programját használó felhasználókból, akik igénybe veszik az ingyenes szoftvert és személyre szóló kulcsot kapnak a szervert üzemeltetố szolgáltatótól, és a keresố rendszerból.

A Martus kliens lehetốvé teszi az emberi jogokkal foglalkozó aktivisták és szervezetek számára, hogy szöveg alapú jelentéseket készítsenek a jogsértésekról. A beépített 
titkosítás biztosítja az adatok védelmét. A Martus szervere fogadja és több különböző helyre elosztva tárolja a tikosított jelentéseket, biztosítva az információk sérthetetlenségét és megelốzve az adatveszteséget. A Martus szerverek ${ }^{4,5}$ a világ különbözó pontjain helyezkednek el. A szerverek tartalma nem egyezik meg, azaz nem minden tartalom jelenik meg valamennyi szerveren. A szerverek tartalmát elóre meghatározott algoritmus alapján tükrözik, és egy biztonsági adatmentésre szolgáló szerver is üzemel. A szervereket nem maga a Martus rendszerét kifejlesztố cég üzemelteti, hanem a vele kapcsolatban álló civil szervezetek.

A Martus keresóprogramja az interneten keresztül hozzáférést biztosít a rendszer felhasználói által elküldött jelentések nyilvános részéhez. A rendszerrel szemben négy fő elvárás támasztható: használhatóság, biztonság, kereshetóség és átláthatóság. Ezeknek az alapelveknek az alkalmazásával biztosítható, hogy a feljegyzések védettek és könnyen hozzáférhetôk legyenek.

\section{Használhatóság}

A kliens program kezelése általános számítógép-felhasználói ismeretket igényel. Használata nem bonyolultabb, mint egy levelezô-programé, és nem igényel állandó hálózati kapcsolatot. A felhasználók (ideértve az emberi jogi sérelmek tanúit is) akár egy internetkávézóból is leadhatják tudósításaikat. A rendszer platformfüggetlen, ami azt jelenti, hogy különbözô operácós rendszereken, Linux vagy Mac esetében éppúgy, mint Windows alatt használható. Nyelvi korlátok nélkül alkalmazható, és a támogatott nyelvek száma a nyílt forráskódú fejlesztéseknek köszönhetốen dinamikusan, az igényeknek megfelelő́en bốvíthetố. A szoftver jelenleg angol, spanyol, orosz, arab, francia és thai nyelven áll rendelkezésre.

A felhasználók választhatnak azok között a lehetôségek között, hogy csak saját maguk számára akarják biztonságos helyen tárolni az információkat, vagy egyúttal nyilvánosságra is akarják hozni azokat. Az elsố esetben csak ók maguk férhetnek hozzá a biztonságba helyezett adatokhoz (ezeket a szerver üzemeltetóje sem tudja elolvasni, még rendốrségi vizsgálat esetén sem), a második esetben pedig azt garantálja a rendszer, hogy az elküldött jelentéseket utólag ne lehessen megváltoztatni, szerkeszteni, manipulálni. Az elküldött jelentés zárt dokumentummá válik és nem módosítható többé. Kiegészítés és módosítás csak újabb bejegyzéssel valósítható meg.

\section{Biætonság}

A biztonság két fő komponens köré épül. Egyrészt a nyílt forráskódú fejlesztésnek köszönhetôen a forráskód szabadon hozzáférhetô, hozzáértô szakemberek által átte-

\footnotetext{
${ }^{4}$ A Nyílt Társadalom Archívuma térségünkben elsóként bocsátott a felhasználók rendelkezésére egy Martus szervert, és kidolgozta a szolgáltatók és felhasználók bizalmi hálózatának irányelveit is.

${ }^{5}$ A rendelkezésre álló szerverek listája a Martus weboldalán érhető el. Jelenleg három szerver üzemel a világon: (Budapest, Seattle, Manila). http://www.martus.org/products/servers.shtml
} 
kinthetô, és a biztonsági hibák javítása gyorsan kivitelezhetô. ${ }^{6}$ A biztonság másik fớ komponens a titkosítás. Az emberi jogi civil szervezetek alkalomszerúen eddig is használtak titkosítási módszereket, azonban a titkosító programok komplexitása megakadályozta azok napi használatát. A Martus egyszerú felhasználói felületet biztosít, miközben magában a programban erôs titkosítási technológiát alkalmaz.

A feljegyzések már a felhasználó számítógépén titkosítva vannak. Az adatátvitel is titkosított csatornán keresztül zajlik, és az adatok természetesen kódolva tárolódnak a „páncélszekrényben" is. A feljegyzések jelszóval védettek. A technológia kialakítása olyan, hogy a személyes feljegyzéseket készítójükön kívül senki sem tudja elolvasni, még a hatóságok szakértói sem. A jelszó elveszítése vagy elfelejtése esetén nem lehet hozzájuk férni.

Az erôs kriptográfiát tartalmazó szoftver az USA exportkorlátozása miatt a következó országokban nem használható legálisan: Kuba, Irán, Líbia, Észak Korea, Szudán és Szíria.

A biztonság harmadik komponensét a Martus szervereire vonatkozó biztonsági előírások képezik. Az informatikai biztonság kérdéskörén belül a szerver fizikai elhelyezését, felügyeletét is szigorúan szabályozza a hagyományosnak mondható szoftveres védelem és elóórások ${ }^{7}$ mellett.

\section{Kereshetóség}

A Martus keresốprogramja a világhálón keresztül 2005 február végén vált elérhetôvé a nagyközönség számára is. Korábban csak a kliens-szoftver használói és a szerver eléréséhez kulcsot kapott felhasználók tudtak a szervereken elhelyezett információk között keresést folytatni. A keresést biztosító Martus szerver Budapesten található és a Nyílt Társadalom Archívum (Open Society Archive) üzemelteti. ${ }^{8}$ A keresés a Martus szervereken elhelyezett nyilvános információkat jeleníti meg.

\section{Átláthatóság}

A bizalom és az átláthatóság megteremtését az biztosítja, hogy a Martus nyílt forráskódú fejlesztési modellben készült. Az ilyen fejlesztések alapgondolata az, hogy amennyiben a programozók láthatják és módosíthatják a szoftver forráskódját, ez nagymértékben felgyorsítja a fejlesztést és sokkal megbízhatóbbá teszi a szoftvert. A Martus felhasználói számára további elónyöket is rejt ez a modell. Sok civil szervezet anyagilag nem képes finanszírozni a kereskedelmi szoftverek beszerzését és használatát, s így a költséges adatbázis-fejlesztésekból is kimarad. A Martus ingyenesen rendelkezésükre áll, anélkül, hogy aggódniuk kellene a szoftverkalózkodás miatt.

A bizalomnak fontos szerepe van a Martus használata során. A felhasználási célterület sajátosságai miatt biztosítani kell, hogy a szolgáltatást tényleg azok használják,

\footnotetext{
${ }^{6}$ A forráskód letölthetô a legnagyobb internetes nyílt forráskódú szoftver projekteknek otthont adó oldalról a sourceforge.net-ról is. http://sourceforge.net/projects/martus/

${ }^{7}$ A Martus szerver és a biztonsági szerver operációs rendszere például csak GNU/ Linux lehet, és naprakészen kell tartani a megjelenô biztonsági frissítésekkel.

${ }^{8}$ A keresố elérhetốsége: http://martus.ceu.hu/
} 
akiknek a fejlesztốk és az üzemeltetốk szánták. A rendszer használatához kapcsolódó stratégiát Székely Iván dolgozta ki. Az egyik elvileg lehetséges megoldás szerint az üzemeltetố dönt arról, hogy kinek ad hozzáférést, a gyakorlatban azonban ez nem kivitelezhetố, részben az azonosítás bonyolult procedúrája miatt, másrészt pedig azért, mert ebben az esetben a szerver üzemeltetójének mintegy cenzorként kellene fellépnie és ez a bizalom alapelveit is sértené. A gyakorlatban a másik lehetôség, a „megosztott felelôsség" alapelve múködik. A szerverhez és a program használatához kulcsot kérốk egy ismert emberi jogi szervezet ajánlását mellékelik kérelmükhöz. Ezáltal a szolgáltatók, a felhasználók és az ajánlók között bizalmi hálózat jön létre.

Abban az esetben, ha a rendszer használatához illetéktelen személy vagy szervezet kapna kulcsot, figyelmeztető üzenet kiküldése után megvonják a hozzáférési jogosultságokat.

\section{Esettanulmányok}

A Martus különbözó elónyöket nyújt a világ különbözố országaiban múködô civil szervezetek számára. Míg a fejlődó országok esetében nagyobb hangsúlyt kap a biztonság és az adatok megvédése a megsemmisüléstốl, illetve az ellopástól, addig a fejlett világ országaiban inkább a dokumentumok rendszerezésének igénye a fontosabb tényezó.

Srí Lanka fontos szerepet játszott a Martus tesztelésében. Itt azonnali és hosszú távú igények is jelentkeztek: hosszú távon a jogvédók által az elmúlt években összegyújtött adatok megốrzése és elemzése, rövid távon pedig a dokumentáció és a biztonságos adatcsere, valamint a kommunikáció volt a legfontosabb. A Fülöp-szigeteken 2003-ban vezették be a Martus rendszer használatát, a biztonságos dokumentációra vonatkozó igények kielégítésére. Az ország különbözô pontjain összegyújtött jelentéseket a központban át tudták nézni és döntést tudtak hozni arról, hogy mely információk váljanak publikussá. Guatemalában a polgárháború 1996-os lezárulta után sok olyan búntett maradt feltáratlanul, amit az emberi jogok sérelmére követtek el, és a búnösök bíróság elé állítása is elmaradt. Az események feltárásán dolgozó újságírókat és aktivistákat 2000 júliusa és 2001. júniusa között 171 esetben érte támadás. A Martus ebben az esetben is az események dokumentálását segítette és az adatok védelmét látta el, amire nagy szükség volt, mivel korábban számos alkalommal ellopták az adatokat tartalmazó számítógépeket.

Az Egyesült Államokban a civil szervezetek sokkal kevesebb biztonsági problémával szembesülnek, mint a korábban említett országokban. Az igény itt elsősorban a dokumentumok rendszerezésére és a biztonsági másolatokra fókuszálódik. A Martus tökéletes eszközt nyújtott az „Arizoniai szövetség a házasságon belüli erôszak ellen” elnevezésú civil szervezet számára. Arizonában az USA államainak átlagánál magasabb volt a házasságon belüli erószak aránya. A szervezet egy tanulmányban kívánta a kialakult helyzetet elemezni és megoldást keresni rá. A tanulmány elkészítéséhez a közös vonások megtalálása érdekében nagy mennyiségú adat összegyújtésére és elemzésére volt szükség. A Martus ebben nyújtott segítséget. Miután betáplálták az események jellemzôiit, a speciális adatok könnyen kereshetôvé, kiválaszthatóvá és rendszerezhetôvé váltak. A Martus segítségével nagy mennyiségú adatot tudtak feldolgozni, miközben értékes visszajelzéseket adtak a fejlesztố cégnek, s ennek köszönhetốen az új funkciók által nyújtott elónyöket most az egész közösség élvezheti. 


\section{Konklúzió}

A társadalmi érték teremtésére épülő üzleti modell a gazdaságilag fejlett országokban évek óta terjed, a társadalmi vállalkozások száma növekszik. A Benetech cég példáján keresztül jól látható, hogyan tudja a technológia a civil szervezeteken keresztül szolgálni az embereket, és a társadalmi vállalkozások hogyan járulhatnak hozzá a társadalmi érték, s ezáltal egy „élhetóbb” világ megteremtéséhez, amire a hagyományos piaci megoldások nem nyújtanak lehetốséget.

\section{Köszönetnyilvánítás}

A tanulmány elkészítésében segítséget jelentett a Martus rendszer létrehozásában nagy szerepet játszott Közép-Európai Egyetemen múködő Nyílt Társadalom Archívumnál ${ }^{9}$ tett látogatás, melynek alkalmából lehetôségem nyílt közelebbrốl megismerkedni a Martus rendszerrel. Külön köszönetemet fejezem ki Székely Ivánnak, aki a Martus rendszer felhasználásának a bizalomra építố alapelveit kidolgozta, valamint Szergej Glusakovnak, aki ellátott technikai információkkal és készségesen végig kalauzolt a Martus rendszerén.

\section{Felhasznált források}

Benetech http://www.benetech.org

Dees, J. Gregory (1998): The Meaning of „Social Entrepreneurship”. http://faculty.fuqua.duke. edu/centers/case/files/dees-SE.pdf

Literature Review on Social Entrepreneurship (2000) (Sherrill Johnson Research Associate Canadian Centre for Social Entrepreneurship)http://www.bus.ualberta.ca/ccse/Publications/ Publications/ Lit.\%20Review\%20SE\%20November\%202000.rtf

Martus http://www.martus.org

Seelos, Christian - Mair, Johanna (2004): Social Entrepreneurship: Creating New Business Models to Serve the Poor. Kelley School of Business, Indiana University (www.sciencedirect.com). 